\title{
Perception towards E-Business Adoption: A Case of Small and Medium Enterprises (SMEs) in Sarawak
}

\author{
Ngian Ek Tee* and Winnie Wong Poh Ming \\ Department of Marketing \\ School of Business and Management \\ University College of Technology Sarawak \\ *Corresponding author: ngianektee@ student.ucts.edu.my
}

\begin{abstract}
E-Business platform is a vital tool that provides SMEs a platform to turn their traditional business into the advance business model. Due to the rapid development of the Internet, it has directed the interest in how to encourage the owner or manager of SMEs in Sarawak. Specifically, this paper examines the influence of need for achievement and risk tolerance factors on attitude towards adoption which directly anticipates e-business adoption in Sarawak's SMEs. The motive of this study was the limited studies related to e-business adoption by SMEs, especially in Sarawak. Furthermore, most e-business studies concentrate on the level of acceptance in the e-business adoption instead of the owner's or manager's attitude towards the adoption. Thus, this limits the understanding about e-business adoption by SMEs in Sarawak, in particular, the need for achievement and risk tolerance factors that influenced the attitude towards the rate of the e-business adoption in Sarawak's SMEs. SPSS 24.0 and SmartPLS 3.0 are used as the main analytical tool which confirmatory factor analysis, convergent validity, discriminant validity and reliability on the measurement model, and tvalue test on the structural model to answer the research objectives. Data were collected from 238 Sarawak's SMEs. A quantitative survey is conducted among the owners or managers of SMEs in Sarawak and purposive sampling method was used for the research. The findings revealed that need for achievement and risk tolerance factor are led to the adoption attitude of Sarawak's SMEs in the adoption of e-business platform. This study validates these variables for e-business adoption among SMEs in Sarawak. Practically, the present findings also extended the current understanding of e-business adoption by Sarawak's SMEs. The results will be useful to SMEs sector, government, and policymakers devising e-business policies. The conclusion and implication of study is outlined.
\end{abstract}

Keywords: Attitude towards e-Business Adoption; e-Business Adoption in SMEs; Needs for Achievement; Risk Tolerance; Sarawak.

\section{Introduction}

Small and medium enterprises (SMEs) is a powerful stimulus for the economic situation. Conversely, they often lack a national location and unable to provide instant services 24 hours a day. Making use of electronic business (e-business) technology has resolve these problems and enabling SMEs to go into larger markets without physical visibility which improve productivity, and provide better communication with business stakeholders. Sarawak's SME has made up of 6.7 percent of overall economic distribution from total SMEs in the country. In the launch of the Business Excellence Seminar and Forum 2017, Datuk Patinggi Abang Abdul Rahman Zohari bin Tun Abang Haji Openg (Chief Minister of Sarawak) stated that "Sarawak is on the right path to achieving its goal to become a developed state with the inception of 
several initiatives to enhance the state's potential in digital economy" (New Straits Times, 2017). From the statement, this highlights that state government is motivating SMEs to introduce technology into their business components.

Nonetheless, SMEs in developing countries such as Malaysia have not completely utilise technology development to improve their business beyond the traditional market. Additionally, there is a need to better comprehend the determinants of e-business adoption which might be related with perception towards the adoption of e-business in SMEs. Several decision of SMEs are depending on the personal characteristics of the owner or manager of enterprise (Chavez, 2016). Recognition of opportunities is the result of a positive business intention and action by owner or manager that driven by their idea that the owner or manager can generate the anticipated results (Welsch, Price, \& Stoica, 2013). Generally, the response of owner or manager beyond extent of existing practice is known as creative response (Schumpeter, 1947), which is affected by a quality decision and the behaviour of social performers (Alam, Md Nor, Ali, Omar, \& Che Wel, 2018). In the present study, the adoption of e-business is a creative response to SMEs as the technology adoption is beyond the existing practice of sampled SMEs. The adoption intention is depending on the knowledge of business owner or manager and the characteristics that influence the adoption of e-business technology. It can be claimed that the adoption of technology in business is delicately-related to the personality of owner or manager of enterprise (Ramayah, Omar, Mohamad, \& Marimuthu, 2012). Specifically, this research attempts to meet the following objectives:

(a) To examine the influence of need for achievement and risk tolerance has a positive influence on attitude towards adoption which directly predicts e-business adoption in SMEs.

(b) To investigate the influence of attitude toward adoption has a positive effect on behaviour intention to adopt the e-business in SMEs.

\section{Theoretical Foundations and Development of Hypothesis}

\section{e-Business Adoption}

"e-Business" is generally specified as trading products or services online, providing services to online consumers, working together with business companions, performing e-learning, and purchases online (Turban, et al., 2017). E-business has also been referred to as the utilising an electronic platform to perform business (Mazzarol, 2015). Meanwhile, e-business is welldefined as an assimilation process of business activities with Information and Communication Technology (ICT) (Wong, 2013). Internet facilities has increase the interconnectedness of the world which dynamic organisations and anticipate simple adoption of modern technologies. SMEs are extra versatile, adapt to transform faster, better development, and acceptance on new ideas than large organisations (Abdullah, Wahab, \& Shamsuddin, 2013). Furthermore, the attitude of the owner or manager in SME serves as a driving pressure for the investment and recognition for the e-business. Additionally, there are quite often for SME's owner or manager to responsive on e-business goals establishment and determine the potential of e-business in their company. Due to these attributes of SMEs, the starter of e-business and fast development of the country become more and more important. There are ample evidence that SMEs are associated with technological innovation (Ahmad, Abu Bakar, Faziharudean, \& Mohamad Zaki, 2014) have studied the adoption of e-business in recent decades.

\section{Need for achievement and Attitude towards Adoption}

A desire to grow or achieve a particular goal is an important factor that can affect business growth. Chavez (2016) has identified that individual with high need of achievement tends to 
find ways to start their own businesses and work better than others. Further, need for achievement has defined as individual that interested to ending up being high achievers with a solid desire for accomplishment (Sajilan, Hadi, \& Tehseen, 2015). However, need for achievement is reasonable and clearly an expectation as a factor to influence that attitudes toward adoption which directly predict e-business adoption in SMEs.

\section{Risk Tolerance and Attitude towards Adoption}

Business owner with risk tolerance personality are willing to commit significant opportunities with a reasonable chance (Kitigin, 2017) which is significant to e-business adoption. Al-dmour, Nweiran, and Al-dmour (2017) have described an individual willing to take risk in their own personality are likely to try new things and always use a new method of working. Risk tolerance as the probability to obtain the rewards related to success of suggested situation, which is needed by an individual prior to be influenced by affects associate to failure (Chere, 2014). Hence, risk tolerance is reasonable and clearly an expectation as a factor to influence the attitudes toward adoption which directly predicts e-business adoption in SMEs.

\section{Attitude towards Adoption on E-business Adoption in SMEs}

Attitude is referring to an individual's mental state which get on ideas or value system, motions, and propensity to act in a manner (Clark, Berkeley, \& Steuer, 2001). Meanwhile, attitude is an evaluative belief toward a particular behaviour. Hoseini and Jafarpour (2016) noted that Interner user's attitude has effected on user actual usage in the organisational context. When user understands the relevance of technology, such as, e-business platform, they have a tendency to play an essential function in commiting to its adoption. In this study, attitude is the result of need for achievement and risk tolerance that at this stage leads to practice of e-business adoption among SMEs in Sarawak. Therefore, the adoption of e-business among SMEs depends on the attitude of owner or manager in SME. Based upon the outcomes of previous research, alternative hypothesis propose in this study are below:

H1 : Need for achievement has a positive influence on attitude towards adoption which directly predicts e-business adoption in SMEs

H2 : Risk tolerance has a positive influence on attitude towards adoption which directly predicts e-business adoption in SMEs.

H3 : Attitude toward adoption has a direct and positive effect on behaviour intention to adopt the e-business in SMEs.

\section{Research Methodology}

\section{Samples and Procedure}

The research site of this study is in Sarawak. This research was specifically targeting owners of SMEs or managers who involved with the decision-making of the company and the choice of SMEs is based on the fact that majority of the companies have used a certain form of ebusiness platform. The sample size was 238 , which is sufficient and remains in accordance with Roscoe's (1975) rule of thumb as the sample size is concerning in 30 to 500 samples (Sekaran \& Bougie, 2016). The researcher employed non-probability sampling technique - the purposive sampling method is adopted to select the samples. Besides, the quantitative method is used to accumulate the primary data in this study. In order to develop multi-item of constructs, 
researcher undertakes a prudent review of the literature. A 7-point Likert-scale was employed for multi-items of each dimension. Need for Achievement is adapted from several sources: Asmara, Djatmika, and Indrawati (2016); Kisira (2013); Sirec and Mocnik (2010); and Isaga (2012). Risk Tolerance is extracted from Asmara, Djatmika, and Indrawati (2016) ; Kisira (2013); Sirec and Mocnik (2010); and Isaga (2012). Besides, attitude towards adoption is adapted from Okadapau and Emaase (2016), Liu (2014), Abroud et al.,(2015), Carlet (2015), and Zainal et al., (2017) and e-business adoption is extracted from Maragia (2016), Ozlen (2014), and Maduku et al., (2016) (Refer to Appendix A).

\section{Findings}

SPSS 24.0 and SmartPLS 3.0 was used in this research study. SPSS was selected because it is preferred in academic and business research, making it one of the most extensively used in statistical analysis (Arkkelin, 2014). Besides, SPSS offers a range of statistical methods, data conversion, and output formats. SmartPLS is a professional statistical technique in evaluates a measurement model and structural model with the purpose to minimize error variance (Chin, 1998).

The data are analysed using SmartPLS 3 which evaluates a measurement model and structural model with the purpose to minimize error variance (Ifinedo, 2011). In terms of distribution assumptions, PLS path modeling is less restrictive and requires smaller sample sizes (Chin, 2010). The researcher conducted descriptive statistics by using SPSS 24.0 to obtain the general information of the respondents as table below:

Table 1 Demographic and Company's General Information of Respondents

\begin{tabular}{|c|c|c|c|}
\hline \multicolumn{4}{|l|}{ Respondent $(\mathbf{N}=\mathbf{2 3 8})$} \\
\hline $\begin{array}{l}\text { Demographic Variable and } \\
\text { General Variable of Company }\end{array}$ & Category & Frequency & $\begin{array}{l}\text { Percent } \\
(\%)\end{array}$ \\
\hline \multirow{2}{*}{ Gender } & Male & 108 & 45.4 \\
\hline & Female & 130 & 54.6 \\
\hline \multirow{5}{*}{ Age Category } & Below 25 years old & 60 & 25.2 \\
\hline & 25 to 29 years old & 69 & 29.0 \\
\hline & 30 to 39 years old & 67 & 28.2 \\
\hline & 40 to 49 years old & 34 & 14.3 \\
\hline & 50 and above & 8 & 3.4 \\
\hline \multirow{6}{*}{ Highest Qualification } & No Formal Qualification & 3 & 1.3 \\
\hline & Primary Qualification (UPSR) & 10 & 4.2 \\
\hline & Secondary Qualification (SPM/STPM) & 74 & 31.1 \\
\hline & College Qualification (Diploma) & 74 & 31.1 \\
\hline & Bachelor Degree & 74 & 31.1 \\
\hline & Postgraduate (Master/PhD) & 3 & 1.3 \\
\hline \multirow{3}{*}{ Ownership Structure of Company } & Sole Proprietor & 35 & 14.7 \\
\hline & Partnership & 54 & 22.7 \\
\hline & Private Limited (Sdn. Bhd.) & 149 & 62.6 \\
\hline \multirow{2}{*}{ The Principles of Company } & Manufacturing & 32 & 13.4 \\
\hline & Service and Other Service & 206 & 86.6 \\
\hline \multirow{4}{*}{ The Age of Company } & Less than a year & 5 & 2.1 \\
\hline & 1 to 3 years & 39 & 16.4 \\
\hline & 3 to 5 years & 38 & 16.0 \\
\hline & More than 5 years & 156 & 65.5 \\
\hline \multirow{2}{*}{ The Total Number of Employees } & Less than five & 63 & 26.5 \\
\hline & 5 to 30 employees & 94 & 39.5 \\
\hline
\end{tabular}




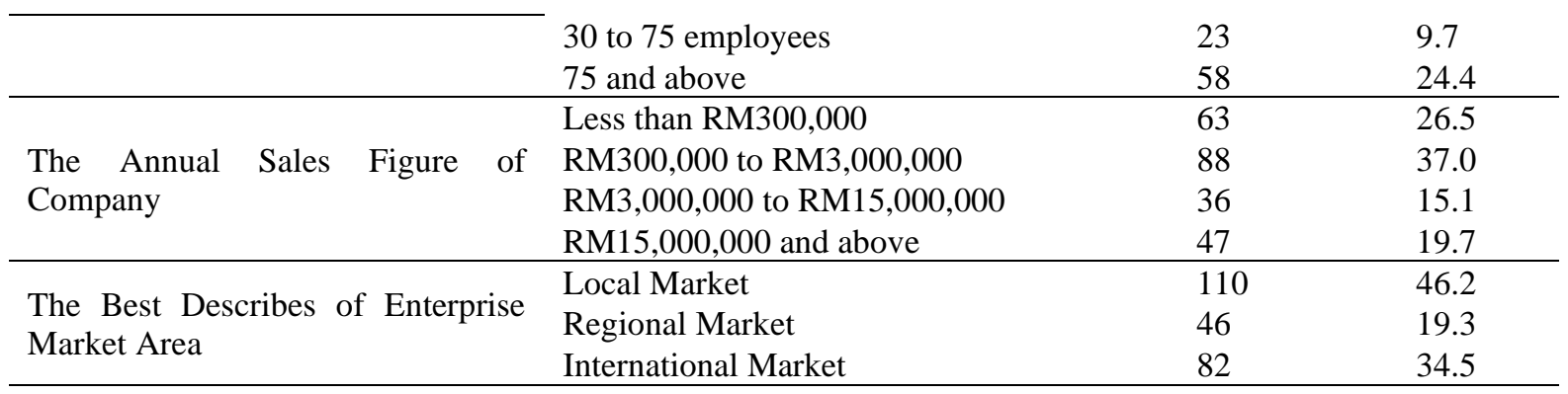

Source: Author

\section{Assessment of the Measurement Model}

The confirmatory factor analysis (CFA) through PLS was utilized to evaluate the measurement model including the convergent validity and discriminant validity. Convergent validity was acquired by Composite Reliability (CR) and Average Variance Extracted (AVE). However, when the square root of AVE exceeds the correlation, there is discriminant validity.

As presented in Table 3, all CR fulfilled the recommended value (0.7) and Cronbach's alpha values exceeded the ultimate value $(0.7)$ as optional by Ramayah, Cheah, Chuah, Ting, and Memon (2018). The results that listed in Table 2 show that the AVE of each model construct surpassed the acceptable level of 0.50 and the item loadings range for each construct was 0.553 to 0.707 , which exceeded the acceptable value of 0.50 as recommended by Hair, Ringle, and Sarstedt (2013).

In conclusion, the model construction of this study achieves decent convergent validity (Bagozzi \& Yi, 1988) with the indication that all indicators have a higher load on the hypothesis factor. Additionally, to develop discriminant validity, the square root of the AVE for a provided construct is contrasted with the correlations between that construct and all vatious other constructs (Voorhees, Brady, Calantone, \& Ramirez, 2016).

Table 2 Loading and Cross Loading

\begin{tabular}{|c|c|c|c|c|}
\hline & $\begin{array}{l}\text { e-Business Adoption } \\
\text { in SMEs }\end{array}$ & Attitude towards Adoption & Need for Achievement & Risk Tolerance \\
\hline Adop_1 & 0.736 & 0.600 & 0.448 & 0.394 \\
\hline Adop_2 & 0.669 & 0.468 & 0.370 & 0.357 \\
\hline Adop_3 & 0.661 & 0.366 & 0.232 & 0.221 \\
\hline Adop_4 & 0.783 & 0.542 & 0.413 & 0.305 \\
\hline Adop_5 & 0.797 & 0.578 & 0.353 & 0.382 \\
\hline Adop_6 & 0.800 & 0.632 & 0.348 & 0.391 \\
\hline Att_1 & 0.602 & 0.807 & 0.454 & 0.418 \\
\hline Att_2 & 0.615 & 0.885 & 0.489 & 0.435 \\
\hline Att_3 & 0.559 & 0.834 & 0.476 & 0.412 \\
\hline Att_4 & 0.613 & 0.838 & 0.521 & 0.426 \\
\hline Att_5 & 0.668 & 0.838 & 0.491 & 0.466 \\
\hline NFA_1 & 0.307 & 0.417 & 0.708 & 0.402 \\
\hline NFA_2 & 0.416 & 0.517 & 0.841 & 0.411 \\
\hline NFA_3 & 0.393 & 0.460 & 0.828 & 0.385 \\
\hline NFA_4 & 0.316 & 0.358 & 0.801 & 0.379 \\
\hline NFA_5 & 0.377 & 0.411 & 0.761 & 0.331 \\
\hline NFA_6 & 0.419 & 0.488 & 0.807 & 0.445 \\
\hline
\end{tabular}




$\begin{array}{lllll}\text { NFA_7 } & 0.420 & 0.459 & 0.680 & 0.607 \\ \text { RT_1 } & 0.418 & 0.416 & 0.493 & 0.790 \\ \text { RT_2 } & 0.314 & 0.371 & 0.418 & 0.804 \\ \text { RT_4 } & 0.235 & 0.305 & 0.256 & 0.618 \\ \text { RT_5 } & 0.397 & 0.423 & 0.430 & 0.749\end{array}$

Note: Bold values are loadings for items that are above the recommended value 0.5.

Source: Author

Table 3 Results of Measurement Model

\begin{tabular}{|c|c|c|c|c|c|}
\hline & $\begin{array}{l}\text { Measurement } \\
\text { Items }\end{array}$ & $\begin{array}{l}\text { Cronbach's } \\
\text { Alpha }\end{array}$ & $\begin{array}{l}\text { Factor } \\
\text { Loadin } \\
\text { gs }\end{array}$ & $\begin{array}{l}\text { Composite } \\
\text { Reliability }\end{array}$ & $\begin{array}{l}\text { Average } \\
\text { Variance } \\
\text { Extracted (AVE) }\end{array}$ \\
\hline \multirow{6}{*}{$\begin{array}{l}\text { E-Business Adoption } \\
\text { in SMEs }\end{array}$} & Adop_1 & 0.838 & 0.736 & 0.880 & 0.553 \\
\hline & Adop_2 & & 0.669 & & \\
\hline & Adop_3 & & 0.661 & & \\
\hline & Adop_4 & & 0.783 & & \\
\hline & Adop_5 & & 0.797 & & \\
\hline & Adop_6 & & 0.800 & & \\
\hline \multirow{5}{*}{$\begin{array}{l}\text { Attitude } \\
\text { Adoption }\end{array}$} & Att_1 & 0.896 & 0.807 & 0.923 & 0.707 \\
\hline & Att_2 & & 0.885 & & \\
\hline & Att_3 & & 0.834 & & \\
\hline & Att_4 & & 0.838 & & \\
\hline & Att_5 & & 0.838 & & \\
\hline \multirow{7}{*}{ Need for Achievement } & NFA_1 & 0.890 & 0.708 & 0.914 & 0.604 \\
\hline & NFA_2 & & 0.841 & & \\
\hline & NFA_3 & & 0.828 & & \\
\hline & NFA_4 & & 0.801 & & \\
\hline & NFA_5 & & 0.761 & & \\
\hline & NFA_6 & & 0.807 & & \\
\hline & NFA_7 & & 0.680 & & \\
\hline \multirow{4}{*}{ Risk Tolerance } & RT_1 & 0.728 & 0.790 & 0.831 & 0.553 \\
\hline & RT_2 & & 0.804 & & \\
\hline & RT_4 & & 0.618 & & \\
\hline & RT_5 & & 0.749 & & \\
\hline
\end{tabular}

Note: a. Composite Reliability $(\mathrm{CR})=$ (square of the summation of the factor loadings)/ (square of the summation of the factor loadings) + (square of the summation of the error variances) $\}$

b. Average Variance Extracted $(\mathrm{AVE})=$ (summation of the square of the factor loadings $) /\{$ (summation of the square of the factor loadings) + (summation of the error variances) $\}$

Source: Author

Table 4 Summary Results of the Model Constructs

\begin{tabular}{llll}
\hline Model Construct & Measurement Item & Standardized estimate & t-value \\
\hline & Adop_1 & 0.736 & 19.432 \\
& Adop_2 & 0.669 & 14.876 \\
Attitude towards Adoption & Adop_3 & 0.661 & 10.767 \\
& Adop_4 & 0.783 & 19.984 \\
& Adop_5 & 0.797 & 25.103 \\
\hline
\end{tabular}




\begin{tabular}{llll}
\hline & Adop_6 & 0.800 & 29.040 \\
\hline \multirow{4}{*}{ E-Business } & Att_1 & 0.807 & 34.429 \\
SMEs & Att_2 & 0.885 & 45.630 \\
& Att_3 & 0.834 & 31.442 \\
& Att_4 & 0.838 & 38.702 \\
& Att_5 & 0.838 & 34.980 \\
\hline \multirow{3}{*}{ Need for Achievemention } & NFA_1 & 0.708 & 15.874 \\
& NFA_2 & 0.841 & 42.668 \\
& NFA_3 & 0.828 & 25.748 \\
& NFA_4 & 0.801 & 25.659 \\
& NFA_5 & 0.761 & 21.843 \\
& NFA_6 & 0.807 & 31.352 \\
& NFA_7 & 0.680 & 13.203 \\
\hline \multirow{2}{*}{ Risk Tolerance } & RT_1 & 0.790 & 19.840 \\
& RT_2 & 0.804 & 26.550 \\
& RT_4 & 0.618 & 8.365 \\
& RT_5 & 0.749 & 19.172 \\
\hline
\end{tabular}

Source: Author

Table 5 Fornell-Larcker Criterion for Discriminant Validity of Constructs

\begin{tabular}{|c|c|c|c|c|}
\hline Constructs & $\begin{array}{l}\text { Attitude towards } \\
\text { Adoption }\end{array}$ & $\begin{array}{l}\text { Need for } \\
\text { Achievement }\end{array}$ & $\begin{array}{l}\text { Risk } \\
\text { Tolerance }\end{array}$ & $\begin{array}{l}\text { e-Business } \\
\text { Adoption in SMEs }\end{array}$ \\
\hline Attitude towards Adoption & 0.841 & & & \\
\hline Need for Achievement & 0.579 & 0.777 & & \\
\hline Risk Tolerance & 0.514 & 0.548 & 0.744 & \\
\hline e-Business Adoption in SMEs & 0.729 & 0.492 & 0.468 & 0.743 \\
\hline
\end{tabular}

Note: Diagonals represent the square root of the average variance extracted while the other entries represent the correlations.

Source: Author

Table 6 HTMT Criterion for Discriminant Validity of Constructs

\begin{tabular}{lllll}
\hline & $\begin{array}{l}\text { Attitude towards } \\
\text { Adoption }\end{array}$ & $\begin{array}{l}\text { Need fchievement } \\
\text { Acher }\end{array}$ & $\begin{array}{l}\text { Risk } \\
\text { Tolerance }\end{array}$ & $\begin{array}{l}\text { e-Business } \\
\text { Adoption in SMEs }\end{array}$ \\
\hline Attitude towards Adoption & & & \\
\hline Need for Achievement & 0.641 & 0.666 & \\
\hline Risk Tolerance & 0.631 & 0.558 & 0.579 \\
\hline e-Business Adoption in SMEs & 0.823 & &
\end{tabular}

Note: HTMT < 0.85 (Kline, 2011), HTMT < 0.90 (Gold, Malhotra, \& Segars, 2001)

Source: Author

\section{Assessment of Structural Model}

Table 5 and Figure 1 show the immediate results of answering the developed hypotheses testing in this research study. The researcher calculated path coefficient $(\beta)$ and t-statistics (t-value) for each of the proposed hypotheses by testing the bootstrapping. The findings showed that the need for achievement was positively related to attitude towards e-business adoption. $(\beta=0.425$, $\mathrm{t}$-value $=4.850$ ); this supporting $\mathrm{H} 1$. The results also gave a standardised Beta, 0.281 from risk tolerance to attitude towards adoption with $\mathrm{t}$-value $=3.023$ and standardized Beta, 0.728 from attitude towards adoption to e-business adoption in SMEs with t-value $=17.374$. Thus, the outcomes indirect that $\mathrm{H} 1, \mathrm{H} 2$, and $\mathrm{H} 3$ were supported.

As suggested by Hair, Hult, Ringle, and Sarstedt (2017), both $\mathrm{R}^{2}$ and $\mathrm{Q}^{2}$ should be included in explaining predictive relevance. In view of this, the Blindfolding procedures were 
also being performed for $\mathrm{Q}^{2}$ value. The $\mathrm{Q}^{2}$ value of the e-business adoption in SME was 0.277, more than zero value which is predictive relevance to the model. Besides, the $\mathrm{R}^{2}$ value of the e-business adoption in SME was 0.531. The researcher tests the overall fit of path model by PLS path analysis modeling. GoF is a global fit measures which is defined as the geometric mean of average communality and average $\mathrm{R}$ square (especially endogenous variables) (Tenenhaus, Vinzi, Chatelin, \& Lauro, 2005). The researcher used the following formula to obtain the GoF value. In this study, GoF value was 0.506 ( $\mathrm{R}$ square $=0.531$, average AVE $=$ 0.483 ). The GoF value exceeded the largest cut-off value, 0.36 . The recommended value of GoFsmall $=0.1$, GoFmedium $=0.25$, and GoFlarge $=0.36$ is the baseline to validate the proposed PLS model in the study (Wetzels, Schroder, \& Oppen, 2009). These results also indicated that the proposed model of this study has better explaining power and confirm that PLS model in this study is sufficient.

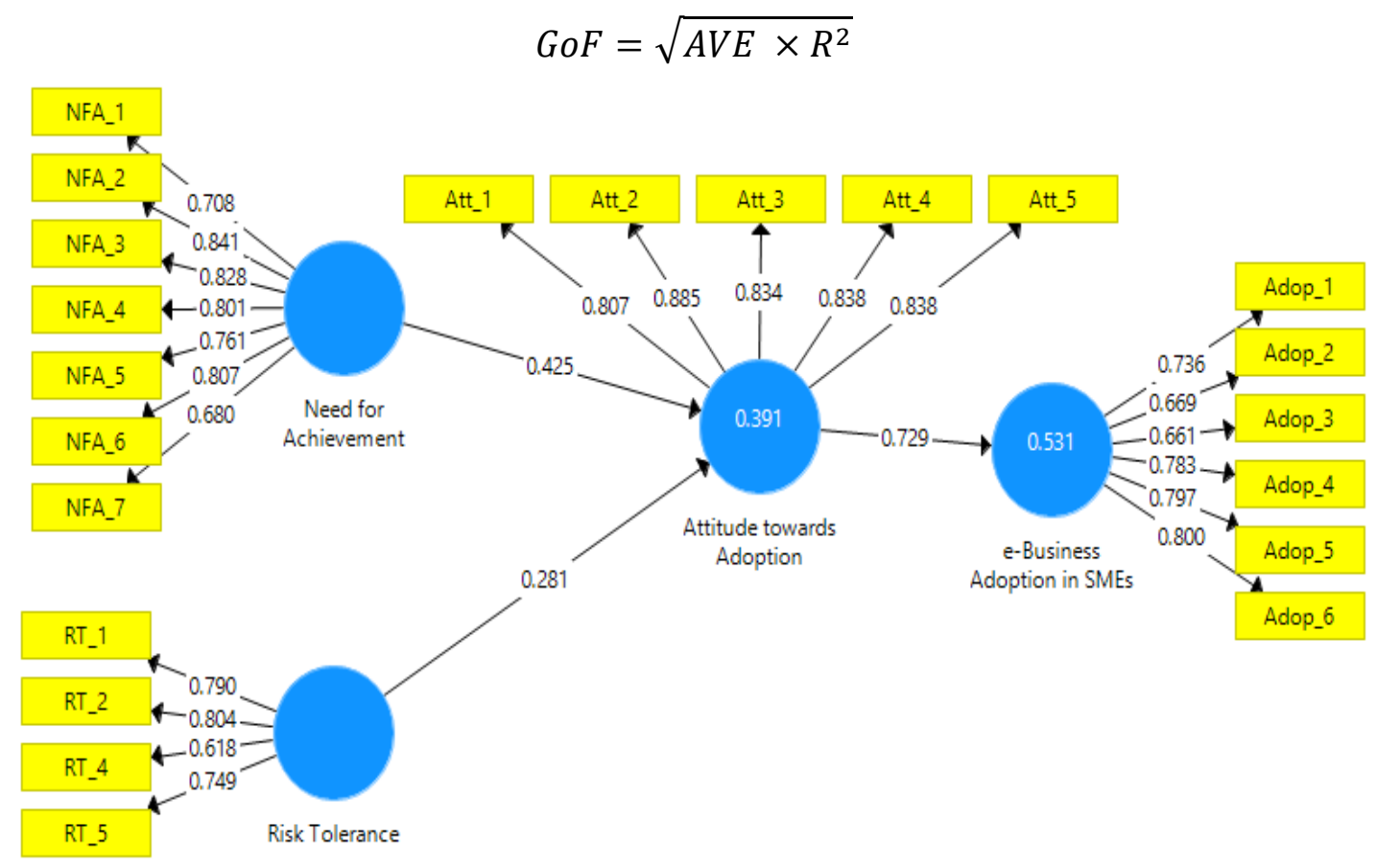

Figure 1: Results of the Path Analysis

Source: Author

\section{Table 7 Path Coefficient and Hypothesis Testing}

\begin{tabular}{lllll}
\hline Hypothesis & Relationship & Coefficient & t-value & Decision \\
H1 & Need for Achievement -> Attitude towards Adoption & 0.425 & $4.850^{* *}$ & Supported \\
H2 & Risk Tolerance -> Attitude towards Adoption & 0.281 & $3.023^{* *}$ & Supported \\
H3 & Attitude toward Adoption -> e-Business Adoption in SMEs & 0.729 & $17.374^{* *}$ & Supported \\
\hline
\end{tabular}

Note: $* \mathrm{p}<0.01, \mathrm{p}<0.05$

Source: Author

\section{Discussion}

The purpose of this study is to investigate the influence of need for achievement and risk tolerance towards adoption attitude which directly predict e-business adoption in SMEs. The 
results have shown that need for achievement and risk tolerance are the factor that determining the attitude to adopt e-business platform in these SMEs. This positive relationship could arise from the fact that the company owners and manager are associated with its business tasks. Specifically, the need for achievement and risk tolerance is statistically significant to the attitude toward adoption which directly predicts e-business adoption in SMEs of Sarawak. Conceivably, the perception of need for achievement and risk tolerance is associated with their educational level. The business owner and manager who has received a better education tends to demonstrate better understanding which assists them to develop business efforts and comprehend business strategic (Wang \& Poutziouris, 2010). This is well-reasoned to influence that attitudes toward adoption which directly predict e-business adoption in SMEs. Besides, the study also shows that increased awareness of e-business platform in SMEs is the perfect way to increase adoption of the technology. The Sarawak government play an important role for improvement that made to encourages the spreading of technology adoption in the area.

\section{Conclusion}

The analysis reveals that need for achievement and risk tolerance were significantly interrelated with the attitude towards adoption which directly predicts e-business adoption in SMEs. The outcomes of the study enhanced the main body of literature in developing of e-business adoption in Malaysia. This work additionally assists to a better comprehend of the determinants of e-business adoption and intention amongst SMEs that led to technology in the country. Generally, it is of aid to the government to understand what influences SMEs owner's attitude, as well as how to encourage them to become involved in the Internet. The generalized findings also will help SMEs to implement consistent technology tools to boost the economy.

\section{References}

Abdullah, N., Wahab, E., \& Shamsuddin, A. (2013). Exploring the common Technology Adoption enablers among Malaysian SMEs: Qualitative findings. Journal of Management and Sustainability, 3(4), 78-91.

Abroud, A., Yap, V. C., Muthaiyah, S., \& Yong, D. G. (2015). Adopting e-finance: Decomposing the technology acceptance model for investors. Service Business, 9(1), 161-182.

Ahmad, S., Abu Bakar, A., Faziharudean, T., \& Mohamad Zaki, K. (2014). An empirical study of factors affecting e-commerce adoption among Small- and Medium-Sized Enterprises in a developing country: Evidence from Malaysia. Information Technology for Development, 21(4), 1-18.

Alam, S. S., Md Nor, N. G., Ali, M. H., Omar, N., \& Che Wel, C. A. (2018). Relationship between entrepreneur's traits and cloud computing adoption among malay-owned SMEs in Malaysia. Cuadernos de Gestion, 18(2), 115-132.

Al-dmour, H., Nweiran, M., \& Al-dmour, R. (2017). The influence of organizational culture on e-commerce adoption. International Journal of Business and Management, 12(9), 204-220.

Arkkelin, D. (2014). Using SPSS to understand research and data analysis. Valparaiso, Indiana: Valparaiso University.

Asmara, H., Djatmika, E., \& Indrawati, A. (2016). The effect of need for achievement and risk taking propensity on entrepreneurial intention through entrepreneurial attitude. Journal of Business and Management, 18(6), 117-126. 
Bagozzi, R. \& Yi, Y. (1988). On the evaluation of structural equation models. Journal of the Academy of Marketing Science, 16(3), 420-435.

Barclay, D., Higgins, C., \& Thompson, R. (1995). The partial least squares (PLS) approach to causal modeling: Personal computer adoption and use as illustration. Technology Studies, 2(2), 285-323.

Carlet, F. (2015). Understanding attitudes toward adoption of green infrastructure: A case study of US municipal officials. Environmental Science and Policy, 51, 65-76.

Chavez, J. (2016). The personality characteristics of an entrepreneur and their effects on the performance of a new business venture. Bachelor's Thesis, Helsinki Metropolia University of Applied Sciences, Finland.

Chere, N. (2014). An analysis of entrepreneurial orientation in selected small and mediumsized enterprises. Unpublished Bachelor's Thesis, North-West University, South Africa.

Chin, W. (1998). The partial least square approach to structural equation modeling. In Marcoulides, G.A. e.d. Mahwah, NJ: Lawrence Erlbaum Associates.

Chin, W. (2010). How to write up and report PLS analyses. In Handbook of Partial Least Squares (pp. 655-690). Berlin, Heidelberg: Springer Berlin Heidelberg. doi:10.1007/978-3-540-32827-8_29

Clark, D., Berkeley, N., \& Steuer, N. (2001). Attitudes to growth among owners of small and medium-sized enterprises and the implications for business advice: Some evidence from the clothing industry in Conventry. International Small Business Journal, 19(3), $72-77$.

Gil-Garcia, J. (2008). Using Partial Least Squares in Digital Government Research. In G. D. Garson, \& M. Khosrow-Pour, Handbook of Research on Public Information Technology (pp. 239-253). Hershey: Idea Group.

Gold, A. H., Malhotra, A., \& Segars, A. H. (2001). Knowledge management: An organisational capabilities perspective. Journal of Management, 18(1), 185-214.

Hair, J. F., Ringle, C. M., \& Sarstedt, M. (2013). Partial least squares structural equation modeling: Rigorous applications, better results and higher acceptance. Long Range Planning, 46, 1-12.

Hair, J., Hult, G., Ringle, C., \& Sarstedt, M. (2017). A primer on partial least squares structural equation modeling (PLS-SEM) (2nd ed.). Thousand Oaks: Sage Publications Inc.

Hoseini, S. \& Jafarpour, Y. (2016). An empirical analysis of the adoption barriers of ecommerce in small and medium sized enterprises (SMEs) with implementation of Technology Acceptance Model. Journal of Internet Banking and Commerce, 21(2), 123.

Ifinedo, P. (2011). An empirical analysis of factors influencing internet/e-business technologies adoption by SMEs in Canada. International Journal of Information Technology and Decision Making, 10(4), 731-766.

Isaga, N. (2012). Entrepreneurship and the growth of SMEs in the future industry in Tanzania. Unpublished PhD Thesis, Vrije Universiteit Amsterdam, Netherlands.

Kisira, D. (2013). Perceived suitability, personality traits, communication channel, and adoption of grid electricity by small firm entrepreneurs in Kagadi Town council. Unpublished Master Thesis, Makerere University, Uganda.

Kitigin, B. (2017). Relationship between risk-taking and business performance among small and medium enterprises in Eldoret Town, Kenya. International Journal of Busienss and Management Review, 5(7), 52-59. 
Kline, R. (2011). Principles and practice of structural equation modeling (3rd ed.). New York: Guilford Press.

Liu, Z. (2014). An analysis of Technology Acceptance Model: Exploring user acceptance and intension of texi-hailing appin Shanghai. Unpublished Bachelor's Thesis, University of Gothenburg, Sweden.

Maduku, D. K., Mpinganjira, M., \& Duh, H. (2016). Understanding mobile marketing adoption intention by South African SMEs: A multi-perspective framework. International Journal of Information Management, 36(5), 711-723.

Maragia, A. (2016). E-Commerce adoption by insurance companies in Kenya. Unpublished Master Thesis, University of Nairobi, Kenya.

Mazzarol, T. (2015). SMEs engagement with e-commerce, e-business, and e-marketing. Small Enterprise Research, 22(1), 79-90.

New Straits Times. (2017, August 23). Sarawak SMEs must embrace technology to prosper, says Abang Johari. Retrieved November 08, 2017, from New Straits Times Press: https://www.nst.com.my/business/2017/08/271548/sarawak-smes-must-embracetechnology-prosper-says-abang-johari

Okadapau, M. O., \& Emaase, P. (2016). Attitude and socio-cultural factors in e-commerce adoption among SMEs in Kenya. International Journal of Engineering and Management Invention (IJEMI), 1(2), 62-72.

Ozlen, M. K., Mekic, E., \& Kumbara, E. (2014). Perceived benefits of e-commerce among manufacturing and merchandising companies. International Journal of Academic Research in Economics and Management Sciences, 3(2), 23-33.

Ramayah, T., Cheah, J., Chuah, F., Ting, H., \& Memon, M. (2018). Partial least squares structural equation modeling (PLS-SEM) using SmartPLS 3.0: An updated and practical guide to statistical analysis (2nd ed.). Kuala Lumpur: Pearson.

Ramayah, T., Omar, A., Mohamad, O., \& Marimuthu, M. (2012). The influence of SME owners' characteristics on technology adoption. Indian Journal of Commerce and Management Studies, 3(3), 10-16.

Roscoe, J. (1975). Fundamental Research Statistics for Behavioral Science (2nd ed.). New York: Holt, Rinehart and Winston.

Sajilan, S., Hadi, N. U., \& Tehseen, S. (2015). Impact of entrepreneur's demographic characteristics and personal characteristics on firm's performance under the mediating role of entrepreneur orientation. Review of Integrative Business and Economics, 4(2), 36-52.

Schumpeter, J. A. (1947). The creative response in economic history. Journal of Economic History, 7(2), 149-159.

Sekaran, U. \& Bougie, R. (2016). Research methods for business: A skill building approach. United Kingdom: John Wiley and Sons Ltd.

Sirec, K. \& Mocnik, D. (2010). How entrepreneurs' personal characteristics affect SMEs' growth. Original Scientific Papers, 56(1/2), 3-12.

Tenenhaus, M., Vinzi, V. E., Chatelin, Y. M., \& Lauro, C. (2005). PLS path modeling. Computational Statistics and Data Analysis, 48, 159-205.

Turban, E., Outland, J., King, D., Lee, J., Liang, T.-P., \& Turban, D. (2017). Electronic commerce 2018: A managerial and social networks perspecive (8th ed.). New York: Springer. 
Voorhees, C. M., Brady, M. K., Calantone, R., \& Ramirez, E. (2016). Discriminant validity testing in marketing: an analysis, causes for concern, and proposed remedies. Journal of the Academy of Marketing Science, 44(1), 119-134.

Wang, Y. \& Poutziouris, P. (2010). Entrepreneurial risk taking: Empirical evidence from UK family firms. International Journal of Entrepreneurial Behaviour and Research, 16(5), 370-388.

Welsch, H., Price, D. P., \& Stoica, M. (2013). Innovation, performance and growth intention in SMEs. Interational Journal of Economic and Management Engineering, 3(5), 176181.

Wetzels, M., Schroder, G., \& Oppen, V. (2009). Using PLS path modeling for assessing hierarchical construct models: Guidelines and empirical illustration. MIS Quarterly, 33(1), 177-195.

Wong, W. P. M. (2013). An investigation on the antecedents influencing customer e-loyalty and e-satisfaction in Malaysia: The mediating effects of trustworthiness. Unpublished PhD Thesis, Universiti Malaysia Sarawak, (UNIMAS), Sarawak, Malaysia.

Zainal, N. T., Harun, A., \& Lily, J. (2017). Examining the mediating effect of attitude towards electronic words-of mouth(eWOM) on the relation between the trust in eWOM source and intention tofollow eWOM among Malaysian travellers. Asia Pacific Management Review, 22, 35-44. 
Borneo Journal of Social Science and Humanities DOI: https://doi.org/10.35370/bjssh.2020.2.1-01 e-ISSN: 2682-8235 (c) 2018, UCTS Publisher.

Appendix A: Measurement Items 


\begin{tabular}{|c|c|c|}
\hline Construct & Source & Items \\
\hline \multirow[t]{4}{*}{$\begin{array}{l}\text { Need } \\
\text { Achievement }\end{array}$} & $\begin{array}{l}\text { Asmara, Djatmika, and } \\
\text { Indrawati (2016) }\end{array}$ & $\begin{array}{l}\text { I will try to catch up with all business by using my competence. } \\
\text { I will try my best to give my best performance for what I have } \\
\text { done previously. }\end{array}$ \\
\hline & Kisira (2013) & $\begin{array}{l}\text { I constantly try to improve my business performance. } \\
\text { I want my business to grow as much as possible. }\end{array}$ \\
\hline & Sirec and Mocnik (2010) & I am driven to ever-greater efforts by an unquenched ambition. \\
\hline & Isaga (2012) & $\begin{array}{l}\text { I look upon my works as simply a way to achieve my goals. } \\
\text { I spend a considerable amount of time making the company I } \\
\text { belong to function better. }\end{array}$ \\
\hline \multirow[t]{4}{*}{ Risk Tolerance } & $\begin{array}{l}\text { Asmara, Djatmika, and } \\
\text { Indrawati (2016) }\end{array}$ & $\begin{array}{l}\text { I will involve in a new trend of business rather than old kind of } \\
\text { business. }\end{array}$ \\
\hline & Kisira (2013) & I see risk-taking as an integral part of a challenging career. \\
\hline & Sirec and Mocnik (2010) & $\begin{array}{l}\text { I am willing to risk my personal and family's material well- } \\
\text { being for the sake of business. }\end{array}$ \\
\hline & Isaga (2012) & $\begin{array}{l}\text { If I invested money in stocks, it would probably only be in safe } \\
\text { stocks from large, well-known companies. } \\
\text { I consider security as an important element in every aspect of } \\
\text { my life. }\end{array}$ \\
\hline \multirow[t]{5}{*}{$\begin{array}{l}\text { Attitude towards } \\
\text { Adoption }\end{array}$} & $\begin{array}{l}\text { Okadapau and Emaase } \\
\text { (2016) }\end{array}$ & Using e-business is important to our company. \\
\hline & Liu (2014) & $\begin{array}{l}\text { I have a generally favourable attitude towards using e-business } \\
\text { platform. }\end{array}$ \\
\hline & $\begin{array}{l}\text { Abroud, Yap, } \\
\text { Muthaiyah, and Yong } \\
(2015)\end{array}$ & Using e-business platform would be a pleasant experience. \\
\hline & Carlet (2015) & $\begin{array}{l}\text { Considering the pros and cons of advance technology } \\
\text { development, I believe e-business adoption of these tools in my } \\
\text { jurisdiction in the near future would be beneficial. }\end{array}$ \\
\hline & $\begin{array}{l}\text { Zainal, Harun, and } \\
\text { Jaratin (2017) }\end{array}$ & $\begin{array}{l}\text { Overall my attitude towards the e-business adoption is } \\
\text { favourable. }\end{array}$ \\
\hline \multirow[t]{3}{*}{$\begin{array}{l}\text { E-Business } \\
\text { Adoption }\end{array}$} & Maragia (2016) & $\begin{array}{l}\text { Our company is connected with the Internet. } \\
\text { Our company has a static website that present company's } \\
\text { information and advertise its products. } \\
\text { Our company accepts online transactions through the website } \\
\text { that allows buying and selling. }\end{array}$ \\
\hline & $\begin{array}{l}\text { Ozlen, Mekic, and } \\
\text { Kumbara (2014) }\end{array}$ & $\begin{array}{l}\text { Companies in Sarawak adopt e-business in order to improve } \\
\text { the ability to serve consumers better and to become more } \\
\text { competitive in the marketplace. } \\
\text { Adoption of e-business influence industries in Sarawak and } \\
\text { structure of the markets within them. }\end{array}$ \\
\hline & $\begin{array}{l}\text { Maduku, Mpinganjira, } \\
\text { and Duh (2016) }\end{array}$ & Our company intends to adopt e-business. \\
\hline Construct & Source & Items \\
\hline \multirow[t]{4}{*}{$\begin{array}{l}\text { Need } \\
\text { Achievement }\end{array}$} & $\begin{array}{l}\text { Asmara, Djatmika, and } \\
\text { Indrawati (2016) }\end{array}$ & $\begin{array}{l}\text { I will try to catch up with all business by using my competence. } \\
\text { I will try my best to give my best performance for what I have } \\
\text { done previously. }\end{array}$ \\
\hline & Kisira (2013) & $\begin{array}{l}\text { I constantly try to improve my business performance. } \\
\text { I want my business to grow as much as possible. }\end{array}$ \\
\hline & Sirec and Mocnik (2010) & I am driven to ever-greater efforts by an unquenched ambition. \\
\hline & Isaga (2012) & $\begin{array}{l}\text { I look upon my works as simply a way to achieve my goals. } \\
\text { I spend a considerable amount of time making the company I } \\
\text { belong to function better. }\end{array}$ \\
\hline
\end{tabular}


Borneo Journal of Social Science and Humanities

DOI: https://doi.org/10.35370/bjssh.2020.2.1-01

e-ISSN: 2682-8235

(C) 2018, UCTS Publisher.

Submitted: 10 September 2019

Accepted: 1 January 2020

Published: 30 June 2020

\begin{tabular}{|c|c|c|}
\hline \multirow[t]{4}{*}{ Risk Tolerance } & $\begin{array}{l}\text { Asmara, Djatmika, and } \\
\text { Indrawati (2016) }\end{array}$ & $\begin{array}{l}\text { I will involve in a new trend of business rather than old kind of } \\
\text { business. }\end{array}$ \\
\hline & Kisira (2013) & I see risk-taking as an integral part of a challenging career. \\
\hline & Sirec and Mocnik (2010) & $\begin{array}{l}\text { I am willing to risk my personal and family's material well- } \\
\text { being for the sake of business. }\end{array}$ \\
\hline & Isaga (2012) & $\begin{array}{l}\text { If I invested money in stocks, it would probably only be in safe } \\
\text { stocks from large, well-known companies. } \\
\text { I consider security as an important element in every aspect of } \\
\text { my life. }\end{array}$ \\
\hline \multirow[t]{3}{*}{$\begin{array}{l}\text { Attitude towards } \\
\text { Adoption }\end{array}$} & $\begin{array}{l}\text { Okadapau and Emaase } \\
\text { (2016) }\end{array}$ & Using e-business is important to our company. \\
\hline & Liu (2014) & $\begin{array}{l}\text { I have a generally favourable attitude towards using e-business } \\
\text { platform. }\end{array}$ \\
\hline & $\begin{array}{l}\text { Abroud, } \\
\text { Muthaiyah, and Yong }\end{array}$ & Using e-business platform would be a pleasant experience. \\
\hline
\end{tabular}

Carlet (2015) Considering the pros and cons of advance technology development, I believe e-business adoption of these tools in my jurisdiction in the near future would be beneficial.

Zainal, Harun, and Overall my attitude towards the e-business adoption is Jaratin (2017) favourable.

E-Business Maragia (2016) Our company is connected with the Internet.

Adoption

Our company has a static website that present company's information and advertise its products.

Our company accepts online transactions through the website that allows buying and selling.

Ozlen, Mekic, and Companies in Sarawak adopt e-business in order to improve Kumbara (2014) the ability to serve consumers better and to become more competitive in the marketplace.

Adoption of e-business influence industries in Sarawak and structure of the markets within them.

Maduku, Mpinganjira, Our company intends to adopt e-business.

and Duh (2016) 